\title{
Prostaglandin Measurement
}

National Cancer Institute

\section{Source}

National Cancer Institute. Prostaglandin Measurement. NCI Thesaurus. Code C103343.

The determination of the amount of the total prostaglandin in a sample. 